\title{
ПРИХОВАНА ПОЛІСЕМІЯ В АНГЛОМОВНІЙ ТА УКРАЇНОМОВНІЙ ІНВЕСТИЦІЙНІЙ ТЕРМІНОЛОГІЇ
}

\section{Олег Сухий}

\author{
Львівський національний університет імені Івана Франка, \\ вул. Університетська, 1, Львів,, Україна, 79000 \\ oleh.sukhyi@lnu.edu.ua
}

\begin{abstract}
На основі визначення антонімічних відношень між різними видами інвестицій в англійській та в українській мовах встановлено полісемію терміна “прямі інвестиції” (direct investment), який потрапляє в різні класифікаційні групи інвестицій залежно від того, яка диференційна сема терміна актуалізується. Проведено дистрибуційний аналіз актуалізації різних сем даного терміна. Запропоновано описувати виявлену полісемію як приховану через те, що в більшості фахових текстів вона явно не проявляється. Розглянуто варіанти введення додаткового уточнюючого прикметника для тих випадків, коли необхідно продемонструвати розбіжності між різними значеннями.

Ключові слова: полісемія, антонімія, інвестиційна термінологія, прямі інвестиції, непрямі інвестиції, портфельні інвестиції.
\end{abstract}

Вступ. Полісемія - важлива властивість семантичної структури багатьох мовних одиниць, яка розглядається як природний наслідок розвитку мови. На протилежність цьому в терміносистемах, де важливою вимогою є однозначність і чіткість термінів, полісемію трактують як небажану. Водночас, як показує практика, цілковито уникнути полісемії в термінології неможливо. Це, зокрема, стосується інвестиційної термінології, яка прийшла в українську мову з англійської у процесі розвитку ринкових відносин в Україні та перекладу відповідних підручників і наукових статей з економіки. Дослідження полісемії, зокрема прихованої, в англомовних та україномовних інвестиційних терміносистемах можемо вважати беззаперечно актуальними.

Аналіз останніх досліджень і публікацій. В останні роки активно почали досліджувати полісемію в термінології різних фахових галузей. Приміром, О. С. Петрина розглянула зовнішню та внутрішню полісемію банківських термінів, приділивши значну увагу конверсії як характерному чиннику полісемії в англомовній терміносистемі [7, с. 189]. Н. Л. Краснопольська дослідила полісемію в україномовній термінології менеджменту і дійшла висновків про поширеність зовнішньосистемної полісемїі й особливу небажаність внутрішньосистемної полісемії [4, с. 368]. Я. М. Тагільцева, О. В. Сільчук та Л. М. Сахарова у своїй роботі щодо омонімії та полісемії в економічному дискурсі виявили семантичну багатозначність - різне тлумачення тих самих термінів авторами різних лексикографічних джерел [5]. Було б помилковим вважати, що полісемія термінів трапляється лише в окремих фахових

(C) Сухий О., 2020 
областях чи лише в гуманітарних науках. Наприклад, Н. А. Цимбал розкрила полісемію в термінології органічної хімії, зокрема категоріальну багатозначність окремих термінів [8, с. 25]. 3. Куньч і Л. Харчук проаналізували полісемію в українській електроенергетичній термінології, окремо видівши міжсистемну полісемію [3, с. 79]. Проте, сьогодні немає спеціалізованих досліджень полісемії в інвестиційній термінології. 3 огляду на це, метою статті стало розкриття полісемії в інвестиційній термінології у відповідних україномовній та англомовній терміносистемах. Крім цього, в більшості наявних досліджень розглядаються полісеманти, які є добре знаними саме як такі у відповідних фахових областях. На противагу цьому, в нашому дослідженні ставимо за мету розкрити варіант полісемії, яка в багатьох фахових економічних текстах взагалі не проявляється й тому пропонуємо розглядати їі як “приховану полісемію”.

Методологія дослідження. Оскільки полісемія в термінології не є поширеним явищем i не завжди явно проявляється, то для виявлення полісемії термінів використано аналіз їхніх антонімічних співвідношень. У випадку наявності у фахових текстах різних антонімів до одного і того ж терміна, можемо стверджувати про полісемію вихідного. При цьому такий аналіз проводиться паралельно в українській та англійській мовах з метою виявити конвергентні та дивергентні риси в обох мовах й отримати зіставлення функціонування таких термінів. На основі встановлення відповідних антонімічних відношень (бінарних опозицій) та проведення їхнього компонентного аналізу було виявлено ключові диференційні семи кожного лексикосемантичного варіанта. Наступним етапом стало проведення дистрибуційного аналізу поєднання ключових диференційних сем у термінах, які описують основні види інвестицій для з'ясування ступеня значимості виявленої полісемії.

Результати дослідження та їхнє обгрунтування. Важливою вимогою до наукових термінів $є$ їхня однозначність. Проте природний розвиток мови веде до набуття нових значень уже відомими лексемами і ця тенденція охоплює i термінологію. Зважаючи на це, В. Даниленко розглядає полісемію наукових термінів як прояв загальної закономірності у розвитку лексики [2, с. 18]. Стосовно наукової термінології такий наслідок можемо вважати небажаним, проте його існування треба визнати закономірною тенденцією.

В межах фахових терміносистем полісемія трапляється значно рідше, ніж серед слів загального вжитку. Це підтверджується емпіричними даними: за розрахунками на основі методики Е. Ф. Скороходька [10] індекс полісемії в досліджуваній фаховій термінології склав 1,03 порівняно із 1,76 у загальній лексиці [8, с. 24]. При цьому, чим ближчий цей індекс до одиниці, тим меншою мірою проявляється полісемія у досліджуваній лексичній системі (врешті, при значенні індексу 1 полісемія цілковито відсутня).

У центрі нашого аналізу перебувають економічні терміни, які позначають основні види інвестицій. Як показує проведене дослідження, в англійській та в українській мовах такі терміни зазвичай складаються із двох лексем, а саме: прикметник (атрибут) + іменник (родове поняття), що відповідає типовим підходам в економічній термінології [12, с. 253]. При цьому у виділенні класифікаційних груп 
інвестицій прикметники-атрибути підбираються так, що вони формують антонімічні бінарні опозиції (тобто прикметники виступають комплементарними антонімами [11, c. 125]), а тому отримані терміни вказують на протилежні поняття і разом номінативно охоплюють усю множину інвестицій. Приміром, за диференційною ознакою наявності інвестиційних посередників в англомовній термінології виділяють direct investment (здійснюються без інвестиційного посередника) та indirect investment (реалізуються через інвестиційного посередника) $[15 ; 16 ; 17]$. Ці класифікаційні види інвестицій повністю дублюються в українській термінології як “прямі інвестиції” - “непрямі інвестиції". За ознакою наявності впливу інвестора виділяють direct investment (присутній вагомий вплив інвестора) та portfolio investment (вплив інвестора незначний), що відповідає українським класифікаційним групам інвестицій “прямі інвестиції” та “портфельні інвестиції” [14; 18].

Як бачимо, термін direct investment - “прямі інвестиції” входить у класифікаційні групи за двома різними диференціальними ознаками і протиставляється, $з$ одного боку, portfolio investment - “портфельним інвестиціям” за ознакою впливу інвестора, a, з іншого боку, він протиставляється indirect investment - "непрямим інвестиціям" за ознакою присутності інвестиційного посередника. Така наявність двох різних антонімів вказує на полісемію цього терміна як в українській, так і в англійській мовах. Іншим цікавим спостереженням $є$ те, що в англійській термінології види інвестицій виражені через словоформу investment, що може мати характеристику або незлічуваного іменника, або однини, тоді як українській мові використовується словоформа “інвестиціи” (множина), тобто наявна дивергентна риса щодо числа іменника, який виражає родове поняття інвестицій.

Полісемія терміна direct investment - “прямі інвестиції” також призводить до того, що в окремих наукових статтях з економіки при відображенні протилежного явища використовується подекуди словосполучення “непрямі (портфельні) інвестиції” [14, с. 26], тобто це термін, який відсутній у лексикографічних джерелах, але вживання якого на практиці ще раз підтверджує наявність полісемії та дуальних антонімічних відношень: непрямі (опосередковані) інвестиції (в значенні відсутності інвестиційних посередників) та портфельні інвестиції (як їх названо у цитованій роботі - “непрямі (портфельні) інвестиції”, коли інвестор не має суттєвого випливу на підприємство). Оскільки подібне уживання знаходимо у статті польського автора, яка перекладена українською мовою, то це наводить на думку про універсальність проблеми полісемії терміна “прямі інвестиціі” та дуальності його антонімічної пари у різних мовах.

Так само, під час класифікації інвестицій за характером участі інвестора Н. М. Гаркуша, О. В. Прокопова та О. Ю. Ляшенко використовують не лише терміни “прямі інвестиції” (direct investment) та “непрямі інвестиції” (indirect investment), але й уточнюють останній термін в українській мові як “непрямі (опосередковані) інвестиції” для того, щоб відрізнити від непрямих (портфельних) інвестицій (portfolio investment) [13]. Оскільки у вищезгаданій науковій праці використовується термін “опосередковані” інвестиції, то, на нашу думку, було б логічно поставити їм у протилежність в україномовній терміносистемі “безпосередні” інвестиції, а не “прямі 
інвестиції”, що дало б можливість усунути дублювання терміна “прямі інвестиції” в різних класифікаційних групах та його полісемію.

Отже, хоча в англійській мові є один і той самий термін direct investment, він, проте, має два значення залежно від контексту, тобто від того, чому він протиставляється (яка диференційна сема актуалізується): портфельним інвестиціям чи опосередкованим інвестиціям. Під час перекладу ми могли б вжити два різних терміни:

1) у першому випадку перекладати direct investment як “прямі інвестиціі” (на противагу непрямим (портфельним) інвестиціям);

2) у другому випадку перекладати direct investment як “безпосередні інвестиції” (на противагу непрямим (опосередкованим) інвестиціям).

У вищеописаний спосіб принаймні в перекладній україномовній термінології ми могли б уникнути полісемії терміна direct investment -“прямі інветиції”, що було б позитивом перекладу. 3 іншого боку, “прямі інвестиції“ $є$ найпростішим і найбільш поширеним варіантом перекладу англомовного терміна direct investment; проте, враховуючи його поширеність запровадити зміни в україномовній термінології за короткий час доволі непросто. Тому на сьогодні в українській мові можемо використовувати прикметники “безпосередні" та “опосередковані" як уточнюючі атрибути, що уже зустрічається в окремих наукових працях й допомагає розмежувати різні значення полісемічного терміна direct investment - “прямі інвестиції".

Термін portfolio investment - “портфельні інвестиціі” викликає чимало питань як у фахівців у ціій галузі [13, с. 86], так і в мовознавців 3 погляду лінгвістичного аналізу та ступеня чіткості окреслення відповідного поняття. По-перше, вживання терміна “портфельні інвестиції” з погляду інвестора при аналізі суті й значення самого терміна зовсім не заперечує можливості мати контрольний пакет у кількох фірмах і формувати свій портфель інвестицій із кількох прямих безпосередніх інвестицій зі значною часткою власності. 3 огляду на це, вживання терміна portfolio investment - “портфельні інвестиції” не можна вважати повністю виправданим й обгрунтованим лише тому, що інвестор формує портфель інвестицій, оскільки процеси диверсифікації (diversification) в сучасній економіці і щодо діяльності підприємств, і щодо інвестування, а саме, вкладання в різні активи, є поширеними та типовими; вони відображають загальновизнані підходи управління інвестиціями, а тому не можуть слугувати адекватною диференційною ознакою, щоб виокремити саме цей тип інвестицій i, відтак, недостатньо чітко окреслюють семантичне значення цьоого терміна.

По-друге, існує практика холдингових компаній (holding company), які володіють диверсифікованим портфелем інвестицій і управляють різними підприємствами, які перебувають у їхній власності, або ж мають контрольний пакет у таких підприємствах. Зважаючи на вищевикладені видові ознаки, такі інвестиції будуть прямими, безпосередніми, а не портфельними, хоча холдингова компанія в даному випадку володіє цілим портфелем інвестицій. Усе це дає підстави вважати за доцільне подальше уточнення терміна portfolio investment - “портфельні інвестиції”.

Виявлена полісемія терміна direct investment - “прямі інвестиціі” існує як в українській, так і в англійській терміносистемах уже впродовж тривалого часу. 
Тому постає питання: наскільки така полісемія значима? I чому це питання досі не вирішено? Насамперед потрібно зазначити, що класифікація за ознакою впливу інвестора (direct investment - “прямі інвестиціï”, portfolio investment - “портфельні інвестиції) була впроваджена міжнародними організаціями i $\epsilon$ поширеною в україномовній та англомовній економічній літературі, а також чітко відображається в міжнародних статистичних даних. За іншою класифікацією міжнародна статистика не ведеться, а тому відповідні їй терміни є менш поширеними. Для поглиблення аналізу значимості виявленої полісемії ми поставили завдання провести дистрибуційний аналіз поєднання чотирьох аналізованих сем (“наявний посередник”, “відсутній посередник”, “істотний вплив інвестора є”, “істотного впливу інвестора нема”), щоб виявити як ці семи поєднуються між собою в реальній практиці й, відповідно, - як співвідносяться між собою direct investment - в “прямі інвестиції” (в обох значеннях цього терміна) та portfolio investment - “портфельні інвестиціі” й indirect investment “непрямі (опосередковані) інвестиціі”. Оскільки переліченим термінам відповідають чотири семи, які перебувають у бінарних опозиціях, то для досягнення означеної мети будуємо матрицю $2 \times 2$, в комірках якої розташовуємо усі аналізовані нами терміни, що відображають відповідні поєднання вищезгаданих сем (див. табл. 1).

Таблиия 1

Матриця співвідношення диференційних сем термінів direct investment - "прямі інвестиції” (в обох значеннях), indirect investment “непрямі інвестиції”, portfolio investment - "портфельні інвестиції”

\begin{tabular}{|c|c|c|c|}
\hline \multicolumn{2}{|c|}{} & \multicolumn{2}{|c|}{\begin{tabular}{c} 
Диференційні семи, \\
\multicolumn{2}{|c|}{}
\end{tabular}} \\
\cline { 2 - 4 } \multicolumn{2}{|c|}{ що характеризують вплив інвесторів }
\end{tabular}


Виявлено, що поєднання аналізованих сем у реальній практиці є таким: найчастіше direct investment - “прямі інвестиціі” за відсутністю посередників передбачають також, що інвестор бажає мати суттєвий вплив на підприємство, а тому такі інвестиції в більшості випадків є також direct investment - “прямими інвестиціями” за ступенем впливу інвестора. Тобто, встановлено і логічно обгрунтовано, що семи “наявність впливу” і “відсутність посередників” найчастіше проявляються разом.

Відтак частка інвестицій, в яких одна із згаданих сем (які входять в поняття direct investment - “прямих інвестицій”) відсутня, а інша присутня, є незначною, що дає змогу науковцям у більшості випадків послуговуватися єдиним терміном direct investment - "прямі інвестиціï" без особливих застережень. Тому ми пропонуємо назвати описаний феномен прихованою полісемією, оскільки значна частина фахівців, що працює з цією термінологією, взагалі не розмежовує ці два значення і не стикається із їхньою розбіжністю. Це добре узгоджується із висновками О. Павлової про те, що чим частіше вживається термін, тим більша імовірність його полісемії [6, с. 320]. В тих нечисленних випадках, коли все-таки необхідне уточнення, найпростішим вирішенням стає введення додаткового прикметника (атрибута) для конкретизації того, яке значення прямих інвестицій актуалізується.

Щодо значення та наслідків описаного феномена прихованої полісемії, то ми поділяємо думку М. Я. Саламахи, яка, описуючи полісемію терміносистеми охорони довкілля, дійшла висновку, що вона не перешкоджає порозумінню між фахівцями [9, с. 17]. Окрім того, в аналізованому нами випадку сама побудова аналізованих термінів “прикметник (атрибут)” + “іменник” дає змогу за потреби легко уточнювати їхнє значення шляхом уведення додаткового атрибуту, що уже трапляється в деяких наукових працях.

Висновки та перспективи подальших досліджень. При класифікації видів інвестицій за різними диференційними ознаками підтверджено полісемію терміна direct investment - “прямі інвестиції” в англійській та в українській мовах. Унаслідок дистрибуційного аналізу ми виявили, що здебільшого direct investment - "прямі інвестиціï” за ознакою відсутності інвестиційних посередників є також і direct investment - “прямими інвестиціями” за ознакою наявності впливу інвестора. I, навпаки, indirect investment - “непрямі інвестиції”, які передбачають наявність інвестиційних посередників, зазвичай потрапляють у категорію portfolio investment - “портфельних інвестицій” за ознакою низького ступеня впливу кінцевого інвестора. Як наслідок, більшість фахівців, що працює з цією термінологією, не відчувають полісемії, що дає нам підстави називати іiі “прихованою полісемією”. В тих випадках, коли вказані розбіжності все ж таки проявляються, доцільним є введення додаткового прикметника (атрибута) для уточнення того, яка диференційна сема актуалізується в обраному контексті. Перспективи подальших досліджень вбачаємо у вивченні інших видів полісемії в економічній термінології, зокрема, інвестиційній, та з'ясуванню їі причин. 


\section{СПИСОК ВИКОРИСТАНОЇ ЛІТЕРАТУРИ}

1. Дудок Р. І. Проблема значення та смислу терміна в гуманітарних науках : монографія. Львів : Львів нац. ун-т, 2009. 358 с.

2. Даниленко В. П. Лексико-семантические и грамматические особенности словтерминов. Исследования по терминологии. Москва, 1971. С. 7-67.

3. Куньч 3., Харчук Л. Полісемія в українській електроенергетичній термінології. Вісник Національного університету “Львівська політехніка". Проблеми украӥнської термінологіï. 2016. № 842. С. 77-81.

4. Краснопольська Н. Л. Полісемія в українській термінології менеджменту. Наукові записки Національного університету “Острозька академія”. Серія : Філологічна. 2010. Вип. 14. С. 362-370.

5. Тагільцева Я. М., Сільчук О. В., Сахарова Л. М. Омонімія та полісемія в економічному дискурсі (на матеріалі сучасної англійської мови). Наукові записки Національного університету “Острозька академія”. Серія : Філологічна. 2017. Вип. 67. С. 261-263.

6. Павлова О. Полісемія в лінгвістичній термінології української мови. Украӥнська термінологія і сучасність : зб. наук. пр. Київ : КНЕУ, 2005. Вип. VI. С. 320-323.

7. Петрина О. С. Смислова варіантність терміна в банківській сфері (на матеріалі англійської та української мов). Вісник Харківського національного університету імені В. Н. Каразіна. Серія : Філологія. 2015. Вип. 73. С. 187-190.

8. Цимбал Н. А. Полісемія в українській термінології органічної хімії. Термінологічний вісник : 3б. наук. пр. К. : ІУМ НАНУ, 2013. Вип. 2(2). С. 22-27.

9. Саламаха М. Я. Англомовна терміносистема охорони довкілля: структура, семантика, прагматика: дис. на здобуття наук. ст. к.ф.н.: 10.02.04. Львів : ЛНУ імені Івана Франка, 2016.

10. Скороходько Э. Ф. Семантические сети и автоматическая обработка текста. Київ : Наукова думка, 1983. 218 с.

11. Сухий О. О. Особливості антонімії в англійській та українській інвестиційній термінології. Науковий вісник Херсонського державного університету. Серія “Перекладознавство та міжскультурна комунікація” 2018. № 2. С. 123-127.

12. Шестакова С. О. Антонімія в економічній термінолексиці. Вісник Дніпропетровського університету імені Альфреда Нобеля. Серія: “Філологічні науки”. 2017. № 1 (13). C. 251-255. 


\section{СПИСОК ВИКОРИСТАНИХ ДЖЕРЕЛ}

13. Гаркуша Н. М., Прокопова О. В., Ляшенко О. Ю. Інвестиції: сутність, види та напрямки. Економічна стратегія і перспективи розвитку сфери торгівлі та послуг. 2009. № 2. C. 82-88.

14. Драбік I. Зростання значення прямих іноземних інвестицій у стратегіях розвитку сучасних підприємств. Економіка та держава. 2008. № 4. С. 23-26.

15. Al-Khouri R. Determinants of foreign direct and indirect investment in the MENA region. The Multinational Business Review. 2015. Vol. 23(2). P. 148-166.

16. Choi S. H., Kim J. J. A Study on the Yield Rate and Risk of Portfolio Combined with Real Estate Indirect Investment Products Journal of Cadastre \& Land InformatiX. 2019. Vol. 49(1). P. 45-63.

17. Fang L., Ivashina V., Lerner, J. The disintermediation of financial markets: Direct investing in private equity. Journal of Financial Economics. 2015. Vol. 116(1). P. 160-178.

18. Lien D., Lo M., Bojanic D. Asymmetric effects of cultural institutes on trade and foreign direct investment. The World Economy. 2018. Vol. 42(5). P. 1520-1553.

\section{REFERENCES}

1. Dudok R. I. Problema znachennia ta smyslu termina v humanitarnykh naukakh: monohrafiia [The Problem of Term Meaning and Sense in the Humanities: monograph]. Lviv : Lviv Nats. Un-t, 2009. 358 p.

2. Danilenko V. P. Leksiko-semanticheskie I grammaticheskie osobennosti slov-terminov. [Lexico-semantic and Grammatical Features of Terms]. Issledovanija po terminologii. Moscow, 1971. P. 7-67.

3. Kunch Z., Kharchuk L. Polisemiia v ukrainskii elektroenerhetychnii terminolohii. [Polysemy Phenomenon in Ukrainian Electricity Terminology]. Visnyk Natsionalnoho universytetu "Lvivska politekhnika”. Problemy ukrainskoi terminolohii. 2016. No. 842. P. 77-81.

4. Krasnopolska N. L. Polisemiia v ukrainskii terminolohi imenedzhmentu. [Polysemy in Ukrainian Terminology of Management]. Naukovi zapysky Natsionalnoho universytetu “Ostrozka akademiia”]. Seriia: Filolohichna. 2010. Vyp. 14. P.362-370.

5. Tahiltseva Ya. M., Silchuk O. V., Sakharova L. M. Omonimiia ta polisemiia v ekonomichnomu dyskursi (na materiali suchasnoi anhliiskoi movy).[Homonymy and Polysemy in Economic Discourse (as exemplified in modern English)].Naukovi zapysky Natsionalnoho universytetu “Ostrozka akademiia”. Seriia:Filolohichna. 2017. Vyp. 67. S. 261-263.

6. Pavlova O. Polisemiia v linhvistychnii terminolohii ukrainskoi movy. [Polysemy in the linguistic terminology of the Ukrainian language]. Ukrainska terminolohiia I suchasnist: Collection of scientific papers. Kyiv : KNEU, 2005. Issue VI. P. 320-323.

7. Petryna O. S. Smyslova variantnist termina v bankivskii sferi (na materiali anhliiskoi ta ukrainskoi mov) [Semantic variants of terms in banking sphere (in Ukrainian and English languages)]. Visnyk Kharkivskoho natsionalnoho universytetu imeni V. N. Karazina. Seriia: Filolohiia. 2015. Issue 73. P.187-190.

8. Tsymbal N. A. Polisemiia v ukrainskii terminolohii orhanichnoi khimii. [Polysemy in Ukranian organic chemistry terminology]. Terminolohichny ivisnyk :Collection of scientific papers. Kyiv : IUM NANU, 2013. Issue 2(2). P. 22-27. 
9. Salamakha M.Ya. Anhlomovna terminosystema okhorony dovkillia: struktura, semantyka, prahmatyka: dys. na zdobuttia nauk. ct. k.f.n.:10.02.04. [The English Term System of Environmental Protection: Structure, Semantics, Pragmatics: Thesis for the Candidate Degree in Philology: 10.02.04]. Lviv : Ivan Franko National University of Lviv, 2016.

10. Skorohodko Je. F. Semanticheskie seti I avtomaticheskaja obrabotka teksta. [Semantic networks and automatic text processing]. K. : Naukovadumka, 1983. 218 p.

11. Sukhyi O. O. Osoblyvosti antonimii v anhliiskii ta ukrainskii investytsiinii terminolohii [Peculiarities of antonomy in English and Ukrainian investment terminology (based on "direct investment")]. Naukovyi visnyk Khersonskoho derzhavnoho universytetu. Seriia "Perekladoznavstvo ta mizhkulturna komunikatsiia". 2018. No. 2. P.123-127.

12. Shestakova S.O. Antonimiia v ekonomichnii terminoleksytsi [Antonymy in the economic terminology]. Visnyk Dnipropetrovskoho universytetu imeni Alfreda Nobelia. Seriia: “Filolohichni nauky". 2017. No. 1 (13). P. 251-255.

\section{SOURCES}

13. Harkusha N. M., Prokopova O. V., Liashenko O. Yu. Investytsii: sutnist, vydy ta napriamky [Investnent: Essence, Classification and Directions]. Ekonomichna stratehiia I perspektyvy rozvytku sfery torhivli ta posluh. 2009. No. 2. P. 82-88.

14. Drabik I. Zrostannia znachennia priamykh inozemnykh investytsii u stratehiiakh rozvytku suchasnykh pidpryiemstv [Increasing significance of foreign direct investment in development strategies of modern companies]. Ekonomika ta derzhava. 2008. No. 4. P. 23-26.

15. Al-Khouri R. Determinants of foreign direct and indirect investment in the MENA region. The Multinational Business Review. 2015. Vol. 23 (2). P. 148-166.

16. Choi S. H., Kim J. J. A study on the yield rate and risk of portfolio combined with real estate indirect investment products. Journal of Cadastre \& Land InformatiX. 2019. Vol. 49 (1). P. 45-63.

17. Fang L., Ivashina V., Lerner, J. The disintermediation of financial markets: Direct investing in private equity. Journal of Financial Economics. 2015. Vol. 116 (1). P. 160-178.

18. Lien D., Lo M., Bojanic D. Asymmetric effects of cultural institutes on trade and foreign direct investment. The World Economy. Vol. 42 (5). P. 1520-1553.

Стаття надійшла до редколегії 26.02.2020 Прийнята до друку 31.03.2020 


\title{
HIDDEN POLYSEMY IN ENGLISH AND UKRAINIAN INVESTMENT TERMINOLOGY
}

\author{
Oleh Sukhyi
}

\author{
Ivan Franko National University of Lviv, \\ 1, Universytetska Str., Lviv, 79000, Ukraine \\ oleh.sukhyi@lnu.edu.ua
}

The purpose of this article is to reveal polysemy in Ukrainian and English terminology denoting types of investment and to find out divergent features between them. It appears that the term direct investment ("priamii nvestytsii" in Ukrainian) both in Ukrainian and English is represented in two different classification groups of investment and can be opposed by portfolio investment (when low investors' influence is meant) or by indirect investment (when emphasis is placed on the absence of investment intermediaries). This brings us to a conclusion on the polysemy of the initial term. The article suggests that this polysemy could be avoided in the Ukrainian language by different translations of the term direct investment depending on the context.

The divergent feature between Ukrainian and English terminology denoting types of investment is that in English the basic term investment is uncountable (it also could be considered singular) whereas in Ukrainian types of investment are represented as investytsii that is plural.

As the polysemy of direct investment has existed in English and Ukrainian for a long time, we have used distributional analysis to reveal how significant this polysemy is for mutual understanding between professionals. On the basis of binary oppositions to the term direct investment, we defined the key semes and then analyzed what their common combinations are in economics. The result is that usually direct investment (in terms of high investor's influence) is also considered as a direct investment in the other meaning (as investor's intermediates are usually avoided in such cases). On the contrary, portfolio investment ("portfelni investytsii") with low investor's influence usually appears to fall into the category of indirect investment ("nepriami investytsii") as investors' intermediates are typically involved. Therefore, in most research papers on economics both in English and in Ukrainian, the polysemy of direct investment ("priami investytsii") does not tmanifest itself. That is why it is suggested to refer to it as "hidden polysemy". In the cases, when it is still important to clarify what exact meaning of direct investment is used, additional attributes or explanations could be added.

Key words: polysemy, antonymy, investment terminology, direct investment, indirect investment, portfolio investment. 